\title{
Performance and egg quality of laying hens fed with dietary levels of digestible lysine and threonine
}

\author{
[Desempenho e qualidade de ovos de poedeiras alimentadas com dietas contendo \\ níveis de lisina e treonina digestíveis] \\ G.O. Figueiredo ${ }^{1}$, A.G. Bertechini ${ }^{2 *}$, E.J. Fassani ${ }^{2}$, P.B. Rodrigues ${ }^{2}$, J.Á.G. Brito ${ }^{3}$, S.F. Castro ${ }^{1}$ \\ ${ }^{1}$ Aluno de pós-graduação - Universidade Federal de Lavras - Lavras, MG \\ ${ }^{2}$ Universidade Federal de Lavras - Lavras, MG \\ ${ }^{3}$ Universidade Federal do Recôncavo da Bahia - Cruz das Almas, BA
}

\begin{abstract}
The present study was developed using 864 Hy-Line W36 laying hens (42 to 58 weeks of age) with a randomized experimental design in a $4 \times 3$ factorial arrangement, with five replicates and 12 birds per experimental unit and 4 evaluation periods of 28 days each. The digestible lysine levels studied were $0.675 \%$, $0.743 \%, 0.811 \%$ and $0.879 \%$, and the digestible threonine levels were $0.542 \%, 0.596 \%$ and $0.650 \%$. The performance and egg quality was evaluated. There were no significant effects on the egg production, specific gravity, albumen and yolk percentage and total solids in albumen and yolk for birds submitted to the different dietary digestible lysine and threonine levels. There was significant interaction between these amino acids on the egg shell percentage and Haugh unit in fresh eggs. There was a decreasing linear effect on the feed intake with increase of digestible lysine level. Egg weight, egg mass and feed conversion demonstrated a quadratic effect with the increase of the digestible lysine level with the best results in the diets with $0.754,0.772$ and $0.795 \%$ of digestible lysine, respectively.
\end{abstract}

Keywords: amino acids, laying hens, crude protein, Haugh unit

\section{RESUMO}

O presente trabalho foi desenvolvido utilizando 864 poedeiras $H y$-Line W36 (42 a 58 semanas de idade) em um delineamento inteiramente casualizado no esquema fatorial $4 x 3$ com 5 repetições e 12 aves por parcela e 4 períodos de avaliação de 28 dias cada. Os níveis de lisina digestível estudados foram 0,675\%; 0,743\%; 0,811\% e 0,879\%, e os de treonina digestível de 0,542\%, 596\% e 0,650\%. Foram avaliados o desempenho e a qualidade dos ovos. Não houve efeitos significativos sobre a produção de ovos, gravidade específica, proporção de clara ou albúmen e seus respectivos teores de sólidos totais para poedeiras submetidas aos respectivos níveis de lisina e treonina na ração. Houve interação entre os níveis de treonina e lisina, para porcentagem de casca e unidade Haugh. Houve redução linear no consumo de ração em função do aumento dos níveis de lisina digestível na ração. Houve comportamento quadrático para peso dos ovos, massa dos ovos e conversão alimentar em função dos níveis de lisina digestível, estimando-se níveis ótimos para respectivas características em 0,754;0,772 e 0,795\%, respectivamente.

Palavras-chave: aminoácidos, poedeiras, proteína bruta, unidade Haugh

\section{INTRODUCTION}

During the past 10 years most of the laying hen strains have shown considerable increases in productivity, primarily stimulated by advances in genetics and nutrition. Despite this development,

Recebido em 21 de março de 2011

Aceito em 27 de janeiro de 2012

*Autor para correspondência (corresponding author)

E-mail: bertechini@ufla.br there are still issues related to nutrition that require more study.

The essential amino acid levels in the diet stand out among the nutritional factors that influence characteristics such as egg size, yolk and albumen deposition, total solids percentage and internal egg quality. 
The formulation of diets for laying hens has evolved on the basis of digestible amino acids that allow better suitability of these nutrients, and contribute to the reduction of nitrogen excretion in the environment. Furthermore, there is a need to update the amino acid recommendations in laying hen diets, in view of the genetic progress and the possibility of different bird response, different environments and changes in production systems (Filho et al. 2006). Due to the importance of lysine for birds, there is great interest in studies with this amino acid in the diet of laying hens, especially because lysine can affect body protein (Valerio et al., 2003) and egg deposition (Ribeiro et al ., 2002).

Threonine participates in protein synthesis and catabolism and generation of many important metabolic products, e.g. glycine, acetyl-CoA, pyruvate (Kidd and Kerr, 1996) and uric acid (Martinez, 1999). This amino acid is found in high concentrations in the heart, muscle, skeleton, central nervous system, and intestinal mucus, and is considered an essential amino acid for birds. It is required for protein formation and maintenance of body protein turnover, and aids in the formation of collagen and elastin, also acting on antibody production (Sá et al., 2007).

Several studies have been conducted to better evaluate lysine and threonine levels in diets of laying hens at different ages. In Brazil, the main reference for ideal amino acid levels are Brazilian Tables of Nutritional Requirements for Poultry and Swine, by Rostagno et al. (2005) and Commercial Strain's Guidelines. It is also true that currently many studies are frequently conducted with these two amino acids to evaluate solid egg yields and internal egg quality.

The suggested lysine and threonine requirements are variable according to crude protein content in diet, but the majority of studies are performed with a low crude protein level and adjusted amino acid profile. Recent studies, under these conditions, have shown that the lysine requirement for actual laying hens is between 760 and $790 \mathrm{mg}$ per day; from 0.76 to $0.79 \%$ in diet, based on a 100 gram per bird intake (Cupertino et al., 2009; Rocha et al., 2009; Silva et al., 2010).

In relation to the threonine requirements, the majority of studies show some differences among results. While Valerio et al. (2002) recommended $0.43 \%$ digestible threonine in diet for maximum performance and egg quality response, Sá et al. (2007) indicated around $0.51 \%$ digestible threonine. In another work, Valerio et al. (2002) concluded that levels above $0.53 \%$ have no response regarding performance or egg quality. Rostagno et al. (2005) indicated a requirement of $556 \mathrm{mg}$ of digestible threonine per day for laying hens in the first production cycle, and this value represents around $0.54 \%$ of digestible threonine in the diet.

Other important factors that might affect the response to the lysine and threonine requirements are evidently the strain of commercial layers, where there are known differences in feed intake capacity, mainly in hot climates, and also the metabolism, body weight and catabolism of endogenous protein (Leeson and Summers, 2001).

The research conducted so far shows results that do not allow us to outline safe levels as well as the effect of these two amino acids on performance and egg quality aspects.

Therefore, the present study aimed to evaluate the performance and egg quality when using various levels of lysine and threonine in the diets of laying hens.

\section{MATERIAL AND METHODS}

The experiment was conducted during the summer, using 864 Hy-Line W36 laying hens at $42-58$ weeks (4 evaluation periods of 28 days each) of age in conventional cages housed at a density of $375 \mathrm{~cm}^{2} /$ bird, with 12 birds in each cage. Cages had galvanized trough type feeders and nipple drinkers, arranged in the upper part with one drinker per two cages.

The treatments were made up of four levels of lysine and three levels of threonine. The lysine levels were $0.675 \%, 0.743 \%, 0.811 \%$ and $0.879 \%$ and the threonine levels were $0.542 \%$, $596 \%$ and $0.650 \%$. We used a random design in a $4 \times 3$ factorial outline with five replicates of twelve birds each. A split plot design with four time evaluation periods of twenty-eight day each was used.

The experimental isonitrogenous $(16.07 \% \mathrm{CP})$ and isocaloric $(2850 \mathrm{kcal} / \mathrm{kg} \mathrm{ME})$ diets were 
based on corn, soybean meal and corn gluten meal, supplemented with minerals, and vitamins (Table 1). Analyses of crude protein of the feed basic ingredients (corn, soybean meal and corn gluten meal) and the experimental diets were carried out at the Laboratory of Animal Research, UFLA, using the Kjedahl method according to AOAC (1990), and the amino acid profile was based on Rostagno et al. (2005). Crystalline amino acids were used in the diet to obtain the studied levels.

Treatments were assigned to each experimental unit and the feed supplied ad libitum twice daily. The experimental diets were prepared biweekly and stored in a cool and airy site. Water was also available throughout the experimental period.

During the research period the number of intact, broken, cracked, shelled and soft shell eggs was recorded daily, the collection being performed twice daily at 10:00AM and 4:00PM. At the end of each week, the weight of whole eggs from each plot and the quality parameters measured in the eggs collected on the last three days of each 21 day period were determined. A 16 hour daily photophase was used for the birds.

The maximum and minimum house temperatures, recorded throughout the experimental period, were 28.8 and $23.2^{\circ} \mathrm{C}$, respectively.

Bird performance was evaluated through the average egg production within 28 days, in percentage per bird per day, being obtained by the number of eggs produced, including cracked, broken or abnormal, and the number of birds per plot that produced them, the average egg weight at the end of each experimental week through the intact eggs collected during the day in each plot and weighed in the evening, food intake in grams consumed per bird per day, egg mass obtained by the product of egg production and the average egg weight in grams, feed conversion calculated by dividing the average feed intake $(\mathrm{kg})$ by the average eggs mass produced (egg weight, $\mathrm{kg} \mathrm{x}$ egg production/100) expressed in kilograms of feed consumed per kilogram of egg production. On the last 3 consecutive days of each period (48th, 51st, 54th and 57th week of age), egg quality was measured in 3 eggs collected randomly each day from each replicate. The eggs were individually weighed and the quality (external and internal) was determined using the QCM System, (Quantum Chromodynamics Microprocessor, Dunnington, UK) mainly Haugh units. After this measurement, all the eggs were broken and their contents removed. The shell with the membranes and the yolk were separated from the albumen and weighed, and their relative proportions were determined. Total solids content in eggs was determined by drying $\left(105^{\circ} \mathrm{C}\right)$ the albumen and the yolk separately.

Table 1. Basal diet composition ${ }^{1}$

\begin{tabular}{|c|c|}
\hline Ingredient & $(\%)$ \\
\hline Corn & 67.88 \\
\hline Soybean meal, $46 \%$ & 17.40 \\
\hline Gluten corn meal, $60 \%$ & 2.50 \\
\hline Sobean oil & 0.82 \\
\hline DL - Methionine, 99\% & 0.26 \\
\hline Limestone & 8.13 \\
\hline Dicalcium phosphate & 1.68 \\
\hline L-Threonine, $98 \%$ & - \\
\hline L-Lysine-HCl, 78\% & - \\
\hline L-Valin, 99\% & 0.040 \\
\hline L-Isoleucin, 99\% & 0.044 \\
\hline Vitamin supplement $^{2}$ & 0.100 \\
\hline Mineral supplement ${ }^{3}$ & 0.100 \\
\hline Salt (Sodium Chloride) & 0.410 \\
\hline Kaolin(inert) & 0.684 \\
\hline \multicolumn{2}{|l|}{ Calculated Nutritional Values } \\
\hline Metabolizable energy, $(\mathrm{kcal} / \mathrm{kg})$ & 2850 \\
\hline Crude protein, $(\%)$ & 16.07 \\
\hline Dig. methionine, $(\%)$ & 0.497 \\
\hline Dig. methinonine+cystine, $(\%)$ & 0.730 \\
\hline Dig. lysine, $(\%)$ & 0.675 \\
\hline Dig. threonine, $(\%)$ & 0.542 \\
\hline Dig. isoleucin, $(\%)$ & 0.618 \\
\hline Dig. valin, $(\%)$ & 0.686 \\
\hline Dig. fenilalanine, $(\%)$ & 0.767 \\
\hline Dig. leucin, $(\%)$ & 1.542 \\
\hline Dig. triptophan, $(\%)$ & 0.159 \\
\hline Dig. arginine, $(\%)$ & 0.927 \\
\hline Linoleic acid, $(\%)$ & 2.039 \\
\hline Calcium, $(\%)$ & 3.603 \\
\hline Available Phosphorus & 0.451 \\
\hline Sodium & 0.180 \\
\hline Chloride & 0.288 \\
\hline Potassium & 0.554 \\
\hline
\end{tabular}

${ }^{1}$ Diet formulated for consumption of $100 \mathrm{~g} / \mathrm{bird} /$ day.

${ }^{2}$ Enrichment per kg feed: Vitamin A: 8,000IU, Vitamin D3: 2,000IU, Vitamin E 15IU, Vitamin K3: 2mg, Vitamin B2: 4mg, Vitamin B6: 1mg, Vitamin B12: $10 \mu \mathrm{g}$, Niacin: 19.9mg, Pantothenic Acid: 5.350mg, Folic Acid: 0.200mg, Selenium: 0.250mg; Antioxidant $100 \mathrm{mg}$. ${ }^{3}$ Enrichment per $\mathrm{kg}$ of diet: Manganese $75 \mathrm{mg}$, Zinc: $70 \mathrm{mg}$, Iron: $50 \mathrm{mg}$, Copper $80 \mathrm{mg}$, Iodine $1.5 \mathrm{mg}$, Cobalt: $0.200 \mathrm{mg}$. 
Specific gravity $\left(\mathrm{g} / \mathrm{cm}^{2}\right)$ was determined by submerging all eggs per replicate (except for 3 eggs collected to determine previously described measurements) in saline-water solutions $(\mathrm{NaCl})$ with density amplitude between 1.066 and 1.102 and a gradient of 0.004 .

Data were submitted to analysis of variance using the statistical package SISVAR (System for Analysis of Variance for Balanced Data), developed by Ferreira (2000). There was adjusted linear regression analysis (quadratic and linear pattern) due to the significant effects of threonine and lysine levels.

\section{RESULTS AND DISCUSSION}

There was no significant interaction $(\mathrm{P}>0.05)$ of the periods and levels of digestible lysine and threonine for the performance measures studied.

There were no significant effects $(\mathrm{P}>0.05)$ on egg production by the levels of the amino acids studied. This result indicates that the need for amino acids is equal to or less than the lowest level used in this work, which was $0.675 \%$ digestible lysine (or consumption of $688 \mathrm{mg}$ of digestible lysine or $773 \mathrm{mg}$ total lysine/bird/day) and $0.542 \%$ threonine in the diet (consumption of $552 \mathrm{mg}$ of digestible threonine, or $620 \mathrm{mg}$ of total threonine/bird/day). The amino acid levels used are probably above the needs of the birds, and therefore had no effect on egg production, reaffirming the recommendations of Rostagno et al. (2005).

There was no significant effect $(\mathrm{P}>0.05)$ of the dietary threonine levels on feed consumption. This result resembles that of Valério et al. (2002), who observed no effect of dietary threonine levels on feed intake in Lohmann LSL layers. However, there were significant effects of lysine levels on feed intake, with a decreasing linear effect $(\mathrm{P}<0.01)$ (Figure 1), with decreased feed intake with increasing levels of dietary lysine. This reduction at the highest lysine levels in the diet can be explained by two theories. In the first, Becovici and Suid (1998) advocated that from a certain daily intake of lysine, the bird reduces feed intake, but the lysine intake remains stable. The second theory is that there was an amino acid imbalance leading to physiological changes with metabolic effects that influence eating behavior. There was an increase in consumption levels of lysine, this being the 2nd limiting amino acid, however, the levels of other amino acids remained stable, resulting in an amino acid imbalance. However, Sá et al. (2007) reported in their work that lysine levels did not affect the food intake of birds.

These results are contrary to those results found by Cupertino et al. (2009) and Rocha et al. (2009) who verified an increase of the feed intake with an increased lysine level in the diet.

There was no significant effect $(\mathrm{P}>0.05)$ of digestible threonine levels in diets on egg weight. This behavior was also observed by Geraldo et al. (2010), on evaluating hens subjected to different threonine levels in diets according to the Nutritional... (1994). In contrast, Huyghebaert and Butler (1991) found better egg weight in birds consuming diets with $0.54 \%$ threonine. A quadratic effect $(\mathrm{P}<0.05)$ was observed for increased levels of lysine (Figure 2) on the average weight of eggs, the maximum egg weight being $63.32 \mathrm{~g}$, obtained with the addition of $0.754 \%$ digestible lysine in the diet, or a consumption of $766 \mathrm{mg}$ of digestible lysine or $798 \mathrm{mg}$ total lysine/bird/day.

Prochaska and Corey (1993) evaluated birds consuming diets with lysine levels from 0.71 to $1.04 \%$, and observed higher egg weight with increasing levels of lysine in the diet. These results are similar to those found by Cupertino et al. (2009) who verified a quadratic response for this measurement and a valuation around $0.71 \%$ digestible lysine. However, these results are different from those found by Silva et al. (2010), in which no significant responses for this measurement were observed.

There was no influence $(\mathrm{P}>0.05)$ of the levels of dietary threonine on egg mass. The need for this amino acid is at or below the first level used in this work: $0.542 \%$ of threonine in the diet, or consumption of digestible threonine $552 \mathrm{mg}$ or $620 \mathrm{mg}$ of total threonine/bird/day. This behavior was also observed by Geraldo (2006), on evaluating hens at peak production fed diets with threonine, formulated according to National... (1994), however, this author found a significant difference between treatments and control diet, which was formulated according to Rostagno et al. (2005), this treatment being superior. Contrary results were reported by Ishibashi (1998), who estimated the level of $453 \mathrm{mg}$ lysine/hen/day for maximum egg mass. 
Performance and egg...

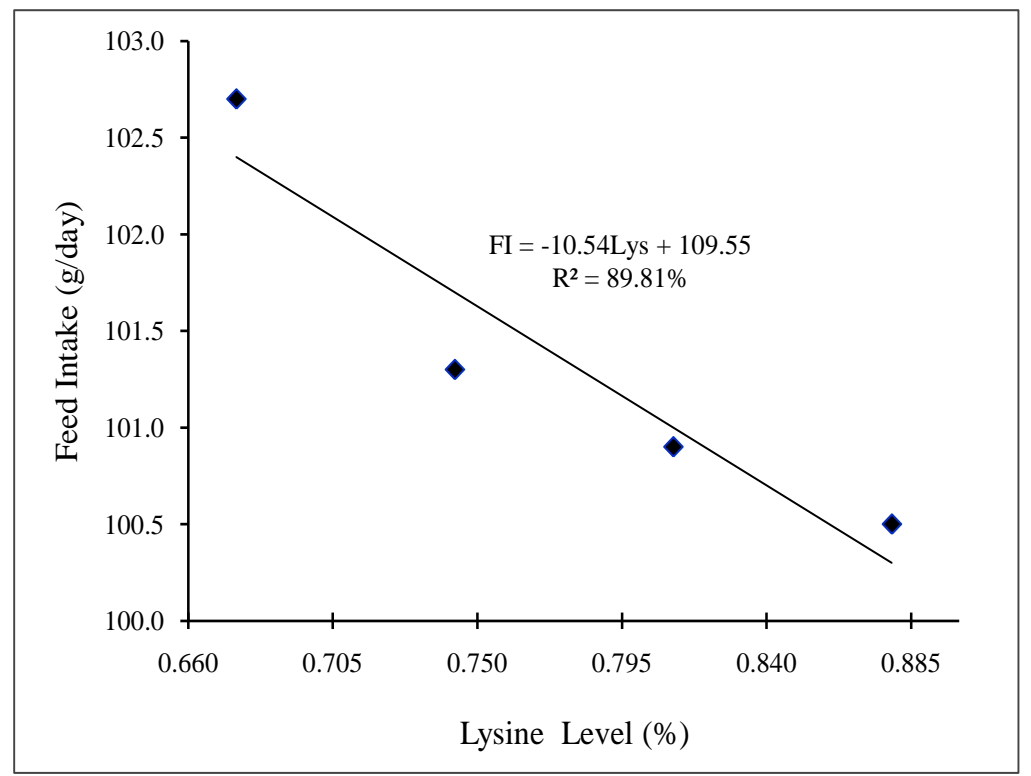

Figure 1. Effects of digestible lysine levels on feed intake.

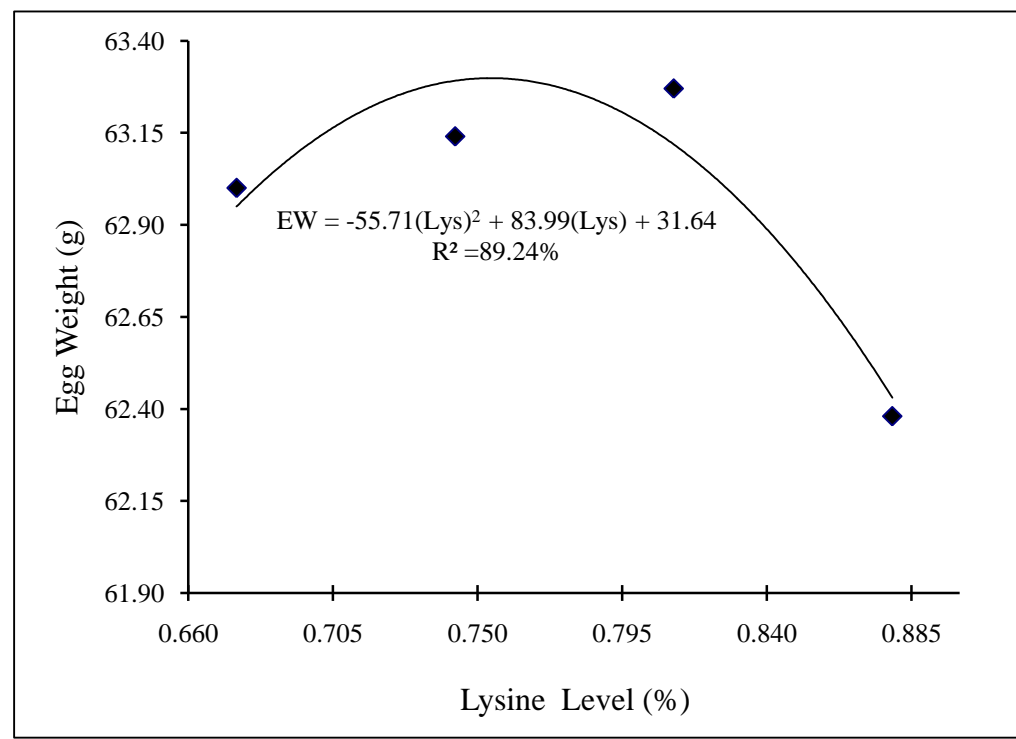

Figure 2. Effects of dietary digestible lysine levels on egg weight.

There was a quadratic effect $(\mathrm{P}<0.05)$ of increased levels of lysine (Figure 3 ) on the egg mass, obtaining a maximum value of 54.54 $\mathrm{g} / \mathrm{bird} /$ day with the addition of $0.772 \%$ of digestible lysine, corresponding to the consumption of lysine $780 \mathrm{mg}$ or $875 \mathrm{mg}$ total lysine/bird/ day (feed intake of $101.3 \mathrm{~g} /$ day).
These results are opposite to those found by Jordão Filho et al. (2006), who did not see this effect in studies with lysine levels.

Note also that there was no influence $(\mathrm{P}>0.05)$ of dietary threonine levels on feed conversion. However, there was a quadratic effect $(\mathrm{P}<0.01)$ of increased levels of lysine (Figure 4 ) on feed conversion. 


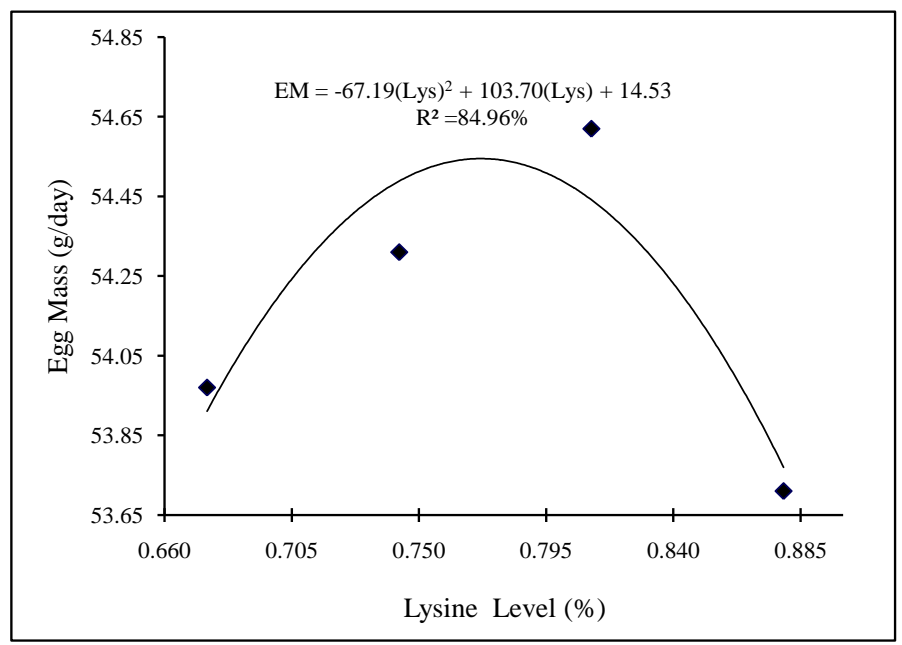

Figure 3. Effects of dietary digestible lysine levels on egg mass.

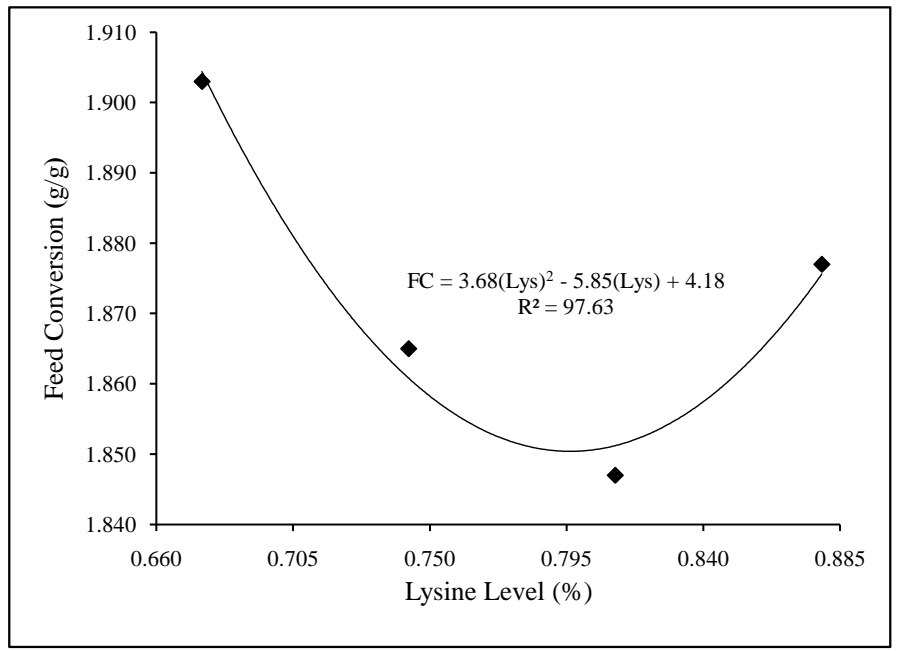

Figure 4. Effects of dietary digestible lysine levels on feed conversion.

The best feed conversion of $1.855(\mathrm{~g} / \mathrm{g})$ was obtained with the addition of $0.795 \%$ of digestible lysine with consumption of $805 \mathrm{mg}$ of digestible lysine/ bird/day. Liu et al. (2005) also assessed birds receiving different levels of dietary lysine and observed improved feed conversion in laying hens consuming higher levels of lysine.

The summarized performance measurement results showed that the data of this study are similar to those found by Rocha et al. (2009) and Silva et al., (2010), for lysine requirements that indicated 0.770 and $0.780 \%$ of digestible lysine to maximize performance requirements for white-laying hens.
The absence of significant response for performance characteristics, with an increase of digestible threonine levels follow other research results (Valério et al., 2002) and this is an indication that requirements to maximize the performance of these laying hens may probably be met by digestible threonine levels lower than $0.542 \%$.

There was no interaction $(\mathrm{P}>0.05)$ between age (periods) and factors studied (digestible threonine and lysine levels in the diet) for the egg quality characteristics, being an indication that the response to the amino acid levels (lysine and threonine) in the diet should be independent of bird age in this evaluated phase. 
However, there was interaction $(\mathrm{P}<0.05)$ between digestible threonine and lysine for egg shell percentage and Haugh unit. At the lowest level of digestible threonine in the study $(0.542 \%)$, there was a quadratic response for egg shell percentage with increased lysine levels in the diet. Therefore, this result can be associated to the amino acid imbalance with the decreasing feed intake that might have negatively affected the intake of nutrients (calcium, phosphorus, vitamins, trace minerals and others) essential for egg shell formation. In contrast to the present result, Liu et al. (2005) and Novak et al. (2004) found no differences in egg shell percentage with increasing lysine levels in the diet.

The egg shell percentage increased linearly with the increasing threonine level at the highest lysine level $(0.879 \%)$. In contrast to the present result, Gomes and Angeles (2009) have reported that eggshell percentage decreased linearly $(\mathrm{P}<0.05)$ as the level of threonine increased in the diet. The explanation for this result is unknown.

There were no significant effects $(\mathrm{P}>0.05)$ for specific gravity according to digestible threonine and lysine (nor their interaction) in the phase studied.

Otherwise, there was interaction among digestible threonine and lysine for the Haugh unit. Within the highest lysine level $(0.879 \%)$, there was a linear pattern $(\mathrm{P}<0.05)$ for this measurement, with reduction in values due to increased digestible threonine levels in the diet. These results might be associated to problems like amino acid imbalances, because the lowest Haugh unit value was obtained (92.58) in the eggs of laying hens of the highest threonine level group. This response was pronounced, because within the highest threonine level $(0.650 \%)$, basically the same result was found, in other words, there was a quadratic Haugh unit pattern $(\mathrm{P}<0.05)$ with increased lysine levels.

Therefore, it is probably high lysine and threonine levels in the laying hens diet, with normal crude protein levels (above 15\%) that could be the factor that harms the albumen quality in function of amino acid imbalance, and consequently affects albumen quality.
These results were similar to those obtained by Schmidt et al (2010) who reported a reduction of the Haugh unit with digestible threonine levels above $0.512 \%$ for laying hens in the second cycle lay. However, the results were contradictory to those found by Cupertino et al. (2009), because these authors verified no effects of lysine levels for the Haugh unit measurement.

There were no interaction or individual amino acid effects on the egg component proportions (albumen and yolk). This result shows that, despite lysine and threonine having been important and essential amino acids, egg internal components are not easily affected, mainly for being associated to the physiological measurements of the laying hen.

These results are similar to those obtained by Rocha et al. (2009), who reported no effects of lysine levels in these measurements of egg components. Likewise, Gomes and Angeles (2009) verified no effects of the same measurements with increased digestible threonine levels in the diet.

The egg solids yield was not affected by amino acid levels (lysine and threonine) and their interactions in the phase studied. These findings indicate that egg processing yield cannot be manipulated by the two amino acids under normal crude protein conditions by white-laying hens.

These results are similar to the findings of Geraldo et al. (2010), Jardim Filho et al. (2004) and Prochaska and Corey (1993), who reported no lysine level effects on egg solids yields. However, in contrast to the present result, Geraldo (2006) found effects of digestible threonine levels on albumen solids.

\section{CONCLUSIONS}

According to responses found under the experimental conditions described herein, we can conclude that for the performance of the birds studied, the minimum levels to maintain egg production were 0.675 and $0.542 \%$ for digestible lysine and digestible threonine, respectively. When the goal is to maximize the egg weight, egg mass and feed conversion, we recommend the dietary level of $0.754,0.772$ and $0.804 \%$ of digestible lysine, respectively. 


\section{ACKNOWLEDGMENTS}

The authors thank FAPEMIG for financial support for the publication of this article, and CNPq for grants awarded to the students.

\section{REFERENCES}

ASSOCIATION of Official Analytical Chemist - AOAC. Official methods of analysis. 15.ed. Arlington, 1990. 1230p.

BERCOVICI, D.; SUIDA, D. Nutrição protéica de frangos de corte. In: SIMPÓSIO SOBRE NUTRIÇÃO ANIMAL E TECNOLOGIA DA PRODUÇÃO DE RAÇÕES, 1998, Campinas, SP. Anais... Campinas, SP: (s.n.), 1998. p.39-49. (Resumo).

CUPERTINO, E.S.; GOMES, P.C.; ALBINO, L.F.T. et al. Exigência nutricional de lisina digestível para galinhas poedeiras de 54 a 70 semanas de idade. Rev. Bras. Zootec., v.38, p.480-487, 2009.

FERREIRA, D.F. Análises estatísticas por meio do Sisvar para Windows versão 4.0. In: REUNIÃO ANUAL DA REGIÃO BRASILEIRA DA SOCIEDADE INTERNACIONAL DE BIOMETRIA, 45. 2000, São Carlos. Anais... São Carlos: Universidade Federal de São Carlos, 2000. p.255-258.

FILHO, J.J.; SILVA, J.H.V.; SILVA, E.L. et al. Exigência de lisina para poedeiras semipesadas durante o pico de postura. Rev. Bras. Zootec., v.35, p.1728-1734, 2006.

GERALDO, A. Aminoácidos sulfurados, lisina e treonina digestíveis para poedeiras comerciais leves em pico de produção. Tese de Doutorado, UFLA, Lavras, Minas Gerais 2006.

GERALDO, A.; BERTECHINI, A.G.; FASSANI, E.J. et al.; Níveis de metionina + cistina digestíveis em rações de poedeiras comerciais no pico de produção. Arq. Med. Vet. Zootec., v.62, p.1216-1224, 2010

GOMES, S.; ANGELES, M.; Effect of threonine and methionine in the diet of laying hens in the second cycle of production. J. App.Poult. Res., v.18, p.452-457, 2009.

HUYGHEBAERT, G.; BUTLER, E.A. Optimum threonine requirement of laying hens. Brit. Poult. Sci., v.32, p.575-582, 1991.

ISHIBASHI, T.; OGAWA, Y.; ITOH, T. et al. Threonine requirements of laying hens. Poult. Sci., v.77, p.998-1002, 1998.

JARDIM FILHO, R.M.; STRINGHINI, J.H.; NASCIMENTO, A.H. et al. Influência dos níveis de lisina sobre o desempenho de poedeiras comerciais - Hy-Line W 36. Rev. Bras. Cienc. Avic., v.6, supl.6, p.104, 2004

JORDÃO FILHO, J.; SILVA, J.H.V.; SILVA, E.L. et al Exigência de lisina para poedeiras semipesadas durante o pico de postura. Rev. Bras. Zootec., v.35, p.1728-1734, 2006 (supl).

KIDD, M.T.; KERR, B.J. L-Threonine for poultry: A review. J. App. Poult. Res., v.5, p.358-367,1996.
LEESON, S.; SUMMERS, J.D. Scott's nutrition of the chicken. Ontario, Canada, University Books, 2001. 414p.

LIU, Z.; WU, G.; BRYANT, M.M.; ROLAND, D.A. Influence of added synthetic lysine in low-protein diets with the methionine plus cysteine to lysine ratio maintained at 0,75. J. Appl. Poult. Res., v.14, p.174-182, 2005.

NATIONAL Research Council - NRC. Nutrient requirement of poultry. 9.ed. Washington, D.C. National Academy Press, 1994. $155 \mathrm{p}$

NOVAK, C.; YAKOUT, H.; SCHEIDELER, S. The combined effects of dietary lysine and total sulfur amino acid level on egg production parameters and egg components in Dekalb Delta laying hens. Poult. Sci., v.83, p.977-984, 2004.

PROCHASKA, J.F.; CAREY, J.B. Influence of dietary lysine on egg production and liquid egg composition. Poult. Sci., v.72, supl. 1, p.186, 1993. Abstract.

RIBEIRO, M.L.G.; SILVA, J.H.V.; COSTA, F.G.P. et al. Efeito dos níveis de lisina e de proteína sobre parâmetros de carcaça e teor de proteína dos ovos de codornas. Rev. Bras. Cienc. Avic., v.4, supl., p.68, 2002.

ROCHA, T.C.; GOMES, P.C.; ROSTAGNO, H.S. et al. Níveis de lisina digestível em rações para poedeiras no período de 24 a 40 semanas de idade. Rev. Bras. Zootec., v.38, p.1726-1731, 2009.

ROSTAGNO, H.S.; ALBINO, L.F.T.; DONZELE, J. et al. Tabelas brasileiras para aves e suínos: Composição de Alimentos e Exigências Nutricionais. Viçosa: UFV, 2005, $186 \mathrm{p}$

SÁ, L.M.; GOMES, P.C.; CECON, P.R. et al. Exigência nutricional de lisina digestível para galinhas poedeiras no período de 34 a 50 semanas de idade. Rev. Bras. Zootec., v.36, p.1829-1836, 2007.

SHMIDT, M.; GOMES, P.C.; DONZELE, J.L. et al. Exigências nutricionais de treonina digestível para poedeiras semipesadas no segundo ciclo de produção. Rev. Bras. Zootec., v.39, p.1099-1104, 2010.

SILVA, J.H.V.; ALBINO, L.F.T., ROSTAGNO, H.S. et al. Exigência de lisina para aves de reposição de 0 a 6 semanas de idade. Rev. Bras. Zootec., v.29, p.1777-1785, 2000.

SILVA, M.F.R.; FARIA, D.E.; RIZZOLI, P.W. et al. Desempenho, qualidade de ovos e balanço de nitrogênio de poedeiras comerciais alimentadas com rações contendo diferentes níveis de proteína bruta e lisina. Rev. Bras. Zootec., v.39, p.1280-1285, 2010.

VALÉRIO, S.R.; GOULART, C.C.; SOARES, P.R. et al. Níveis de suplementação de treonina para poedeiras comerciais leves e semi-pesadas. In: REUNIÃO ANUAL DA SOCIEDADE BRASILEIRA DE ZOOTECNIA, 39, 202, Piracicaba. Anais... Piracicaba: Editora Folha de Viçosa, 2002. p.68-70.

VALÉRIO, S.R.; OLIVEIRA, R.F.M.; DONZELE, J.L. et al. Níveis de lisina digestível em rações mantendo-se ou não a relação aminoacídica, para frangos de corte de 1 a 21 dias de idade, sob condições de estresse por calor. Rev. Bras. de Zootec., v.32, p.361-371, 2003. 